\title{
The Export Behavior Of Domestic And Transnational Firms In Brazilian Manufacturing*
}

\author{
by \\ PAUL A. NATKE \\ Central Michigan University \\ Abstract
}

Some developing nations face mounting foreign debt and a need to generate greater export earnings. Reaction by individual firms to government solutions (e.g. export incentives) will determine whether such efforts will succeed. Transnational corporations are often viewed as superior to Brazilian firms as exporters and evidence here suggests they are. As foreign ownership rises so does export propensity. The influence of export subsidies is mixed suggesting that overall government policy is more important than one specific policy. Comparative advantage does not appear to exert a strong influence at the firm level.

Growing problems of financing external indebtedness have forced many developing nations to more closely examine their export performance. Some nations have adopted a development strategy which encourages foreign direct investment and depends on a trade surplus to promote high rates of growth in the economy and, in particular, the manufacturing industries. Often a crucial agent in such a development plan is the transnational corporation (TNC). The trading performance of manufacturing TNCs has been scrutinized both by developing host nations, which often perceive TNCs as doing too little to promote export growth and balanced trade, and by academic economists in search of objective measures of trade performance and underlying motives for TNC behavior. The scrutiny of TNCs has paralleled their increasing importance in world trade. Helleiner (1981) has estimated that 25-33 percent of all international trade is intrafirm while Helleiner and Lavergne (1979) suggests that 54 percent of manufactured goods imported to the United States in 1977 were intrafirm transactions. Understanding trade flows, therefore, becomes increasingly dependent on understanding firm-level behavior.

This paper examines the export behavior of firms in Brazilian manufacturing industries to determine if there are substantial differences between TNC subsidiaries and domestic firms; whether the extent of foreign control (ownership) alters export performance; and attempts to isolate some determinants of export behavior in industrial structure and firm characteristics.

The paper begins with a brief analytical background, followed by a statement of hypotheses and explanation of the variables. Section four examines the statistical results. A summary concludes the paper.

\section{Analytical Background}

TNCs are often envisioned as powerful promoters of export growth. They have access to the world's largest markets through their expertise in tech-

*I wish to thank Richard S. Newfarmer of the World Bank for allowing me to use the basic data employed in this article and providing many useful comments on earlier drafts. 
nology, management and product differentiation. Parent firms may control home national markets (Helleiner 1973) or have greater knowledge of export opportunities than domestic firms. The financial and information resources of TNCs allow them to separate stages of the production process to exploit cost differentials (e.g. wages, taxes) among nations. That TNCs often operate in many nations is testimony to their ability to overcome market imperfections (both internal and external) and use them to their advantage.

Foreign direct investment is encouraged in some developing nations, in part, because of the perceived superior export performance of TNCs. Some observers, however, may expect too much. Not all TNC subsidiaries can be export bases and their location in the developing world may hinge on perceptions by the TNC (e.g. political stability) as well as cost factors (e.g. wages and taxes). Proximity to major markets, industrial and technological development, the level of export incentives, and barriers to the transfer of profits are reasons TNC export activity will vary across developing nations.

Even if domestic firms in an identical industry face similar production costs and government policies, TNCs may still be expected to export more than domestic firms. International investment theory suggests that to overcome the greater cost associated with operating foreign subsidiaries at a distance, the TNC must possess some monopolistic advantage it can profitably exploit. These advantages may serve as a basis for penetrating other foreign markets.

Various studies present conflicting evidence on whether TNCs operating in developing countries have different tendencies to export than their domestic counterparts (Cohen 1973, Jenkins 1979, Katrak 1983, Lall and Kumar 1983, Lall and Mohommed 1983, Newfarmer and Marsh 1981, Wilmore 1976). Some of these studies merely compare sample statistics without controlling for other influences on behavior such as capital intensity, firm growth or market concentration. Others test their models using industry-level data and then make inferences about firm behavior. Some focus on firm behavior but only in one industry while one study (Glejeser 1980) of a large sample of Belgian firms does not directly address the ownership issue.

This study attempts to fill some of the gaps in the empirical literature by using a large sample of firm-level data, focusing on one developing nation (Brazil), and controlling for potential non-ownership influences on export behavior.

Hypotheses and Variables

This paper's measure of export propensity is EXPROP: the percentage of a firm's total sales that are exports. The effects of foreign ownership alone on firm export propensity is uncertain. Subsidiaries have connections in a network of international production which can be an outlet for intermediate goods. For final goods, established marketing and distribution networks of the parent firm may make penetration of markets in the developed world an easier task especially if the parent firm controls the home nation market. Finally, price competition in the nation of the parent firm may increase export propensity by encouraging the establishment of assembly operations to take advantage of low wages for low-skilled or semi-skilled labor in developing countries.

Alternatively, one could argue that the primary motivation for foreign direct investment is to service the large Brazilian market with production facilities and, therefore, production for export is of secondary importance. Furthermore, the parent firm may allocate foreign markets among its subsidiaries in order to avoid competition for markets within the global corporation and increase total profits. Corporate restrictions on subsidiaries' exports 
are quite common particularly for those goods embodying high technology or produced under license, (Vaitsos 1974; Jenkins 1979).

The advantage of domestic firms lies in the traditional industries. Their exports might be greater if major distributors in developed nations (e.g. Sears and $\mathrm{K}$-Mart) are willing to experiment with low-priced imports. In engineering industries, exports are promoted by the Brazilian government through the use of subsidized credit for the producer or purchaser, tax exemptions, and outright cash grants. The inclusion of subsidy and product differentiation varibles in regression analysis are designed to control for these influences.

Katrak (1983) offers an alternative hypothesis by arguing that the extent of foreign control over a subsidiary (and not the mere presence of foreign ownership) influences its export behavior. Two cases are treated: one where the parent and subsidiary export competing products to an unrelated party; and another where the host subsidiary exports to a sister subsidiary in a third nation and the parent does not trade with either affiliate. He concludes from the first-order conditions for global profit maximization, that the greater the parent's ownership share of the subsidiary the greater is the amount exported from that subsidiary.

Foreign ownership is measured in two ways. First, a set of dumy variables was created. Any firm with greater than 25 percent of its common stock held by foreigners was classified as a TNC. The variable OWN takes a value of one when the firm is a TNC as defined above; zero when it is a Brazilian firm. Similar dummy variables were created for STATE (government owned), US (parent firm from the United States) and WECJ (parent firm in western Europe, Canada or Japan). The second ownership variable is FOROWN which measures the percentage of foreign stock owner-ship. It is included to test the Katrak (1983) hypothesis.

Export performance is determined by other firm-level influences such as capital intensity. The firm's price competitiveness in international markets is dependent on the cost conditions of individual firms and the structure of resource prices in Brazil. For the mature technologies prevalent in Brazilian manufacturing, relative factor costs become important. Brazil's relatively low wage structure implies that firms with higher capital intensities will have lower export propensities. An alternative argument suggests that capital intensity is an indicator of the degree of technological sophistication inherent in the production process. High-technology goods may be better able to overcome marketing barriers to entry in the developed nations and increase export propensity. Capital intensity is measured by CAPINT: the ratio of total assets to gross operating revenue. This variable deviates from a direct measure of factor intensity (the capital-labor ratio). The use of the capital-output measure CAPINT does confuse the effects of capital intensity of production (the capital-labor ratio) with labor productivity (labor-output ratio). Either a higher capital-labor ratio or a lower labor productivity can increase the capital-output ratio. Fortunately, each effect leads to higher production costs and lower exports in the Brazilian case.

Although the variables reflecting industry characteristics are intended as control measures, they may have a substantial impact on export propensity. From the theoretical literature on pure trade under protection it is clear that firms in more concentrated markets will have a higher propensity to export if their final goods are price competitive in foreign markets (White 1974). This will be particularly important in those industries whose high ownership concentration is due to economies of scale in production (economies which are large relative to the size of the domestic market) or in marketing (which may be easily applied to other markets). Firms attempting to increase sales in domestic markets would face falling profits. Therefore, these firms attempt to 
diversify in the domestic economy or seek out foreign markets and often pursue both strategies simultaneously.

Others (including Glejser 1980) have argued that domestic market concentration has a negative impact on a firm's share of exports in total sales. If the dominant firms achieve economies of scale in the home market, the competitive fringe may be unable to reach the critical size necessary for exportation of their products. Furthermore, dominant firms may avoid exporting by exploiting domestic demand. Exporting would increase the demand elasticity, weaken oligopolistic interdependence, and erode collusion. The statistical results presented below may provide a clue as to which of these influences is predominant in Brazil.

Concentration is measured by the share of the four leading plants in industrial sales for 1973 as calculated from an industrial census (Tavares 1978). The CR4 for a firm is a weighted average of concentration ratios for the five markets in which a firm's largest selling products were sold. If product information was unavailable, CR4 represents the four-plant concentration ratio for the industry assigned to the firm.

Industry advertising (INAD) is a rough measure for the degree of product differentiation. Standardized goods may find more outlets abroad, particularly in other developing nations, than differentiated ones. As it is doubtful that Brazil has much influence on foreign tastes (i.e. is a "trend-setter" in world markets), INAD should be negatively related to export propensity.

Government export incentives are designed to increase export propensity by making final goods more price competitive in foreign markets. However, the subsidies may not be an effective method of encouraging TNCs to export. The export decisions of TNC subsidiaries may be constrained by the parent firm in the interests of global strategy; export gains by one subsidiary may lead to a greater loss of profits for another subsidiary it might compete with (Katrak 1983). Furthermore, a subsidiary tied to an international network of production may have its exports primarily determined by the production schedules of its related buyers.

Export incentives may also have little effect on the performance of some domestic firms. If the overall effect of a coordinated program of incentives and tariffs is to keep inefficient Brazilian firms operating, the existence of incentives may not encourage exporting behavior. Brazilian firms may be satisfied with their profits earned on domestic sales and such firms may not be sufficiently price competitive in world markets, even with incentives, to maintain a substantial level of exports.

SUBSIDY represents the rate on fiscal incentives for the export of manufactured goods during 1977 (Tyler 1981). This measure may not accurately reflect actual subsidy rates available to a firm because the variable represents an average of rates offered on individual products grouped under particular industries. The actual subsidy rate faced by firms may be substantially different if the composition of their exports differs from the average for the industry. However, the firm level data used here does not allow us to identify these unrepresentative firms or use a more appropriate weighting scheme. Despite this limitation, SUBSIDY is included here to avoid misspecification of the model.

Empirical Results

The test of means in Table 1 shows that domestic firms export a larger percentage of sales (5.99 to 5.00) than TNCs although the difference is not statistically significant. This difference might, in part be attributable to 
the higher subsidies received by domestic firms. This assertion awaits further support in the regression results below where other influences are controlled for. Brazilian firms are, on average, larger than TNCs in terms of assets and capital intensity while TNCs have greater sales and produce in markets with higher levels of advertising intensity.

TABLE 1

Comparison of Sample Means Between TNC and Brazilian Firms

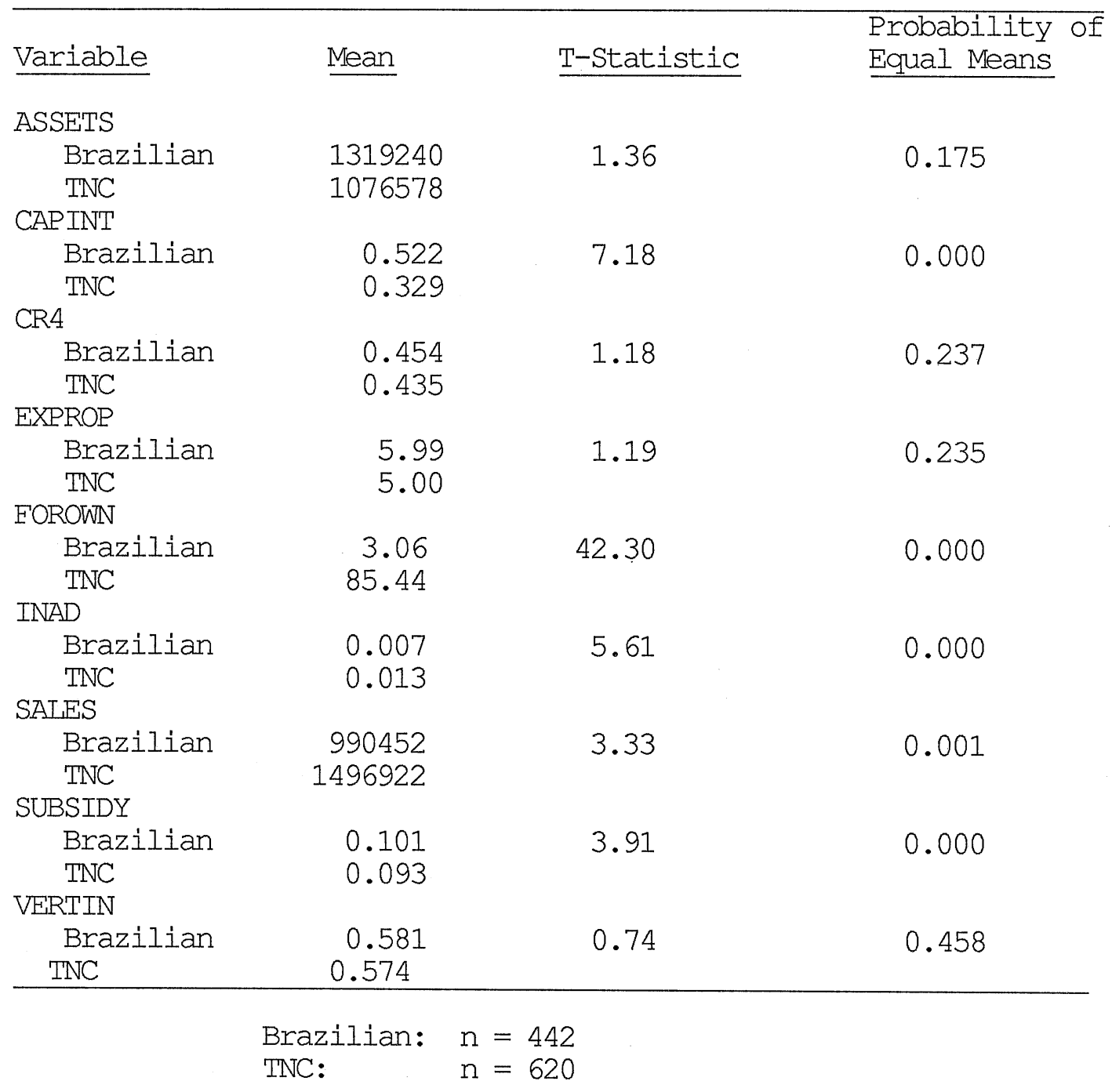

Among TNCs, those with a U.S. parent have greater levels of foreign ownership, are more vertically integrated and sell in markets with greater levels of concentration (see Table 2). Non-U.S. subsidiaries, on the other hand, receive greater export subsidies from the Brazilian government. National origin, however, exerts no influence on export propensity. Whether any difference in export behavior exists among TNCs of different national origins once these differences in firm operations etc. are controlled for is examined below.

Several alternative specifications of the regression model are presented 
TABLE 2

Comparison of Sample Means Between U.S. and non-U.S. TNCS

\begin{tabular}{|c|c|c|c|}
\hline Variable & Mean & T-statistic & $\begin{array}{l}\text { Probability of } \\
\text { Equal Means }\end{array}$ \\
\hline ASSETS & & & \\
\hline $\begin{array}{l}\text { US } \\
\text { non-US }\end{array}$ & $\begin{array}{r}998000 \\
1133705\end{array}$ & 0.98 & 0.328 \\
\hline CAPINT & & & \\
\hline $\begin{array}{l}\text { US } \\
\text { non-US }\end{array}$ & $\begin{array}{l}0.313 \\
0.341\end{array}$ & 1.28 & 0.201 \\
\hline CR4 & & & \\
\hline $\begin{array}{l}\text { US } \\
\text { non-US }\end{array}$ & $\begin{array}{l}0.470 \\
0.409\end{array}$ & 2.72 & 0.007 \\
\hline EXPROP & & & \\
\hline $\begin{array}{c}\text { US } \\
\text { non-US } \\
\text { FOROWN }\end{array}$ & $\begin{array}{l}5.21 \\
4.86\end{array}$ & 0.48 & 0.628 \\
\hline $\begin{array}{l}\text { US } \\
\text { non-US }\end{array}$ & $\begin{array}{l}91.33 \\
81.17\end{array}$ & 2.38 & 0.018 \\
\hline INAD & & & \\
\hline $\begin{array}{l}\text { US } \\
\text { non-US }\end{array}$ & $\begin{array}{l}0.132 \\
0.122\end{array}$ & 0.76 & 0.451 \\
\hline SALES & & & \\
\hline $\begin{array}{l}\text { US } \\
\text { non-US }\end{array}$ & $\begin{array}{l}1264969 \\
1665557\end{array}$ & 1.53 & 0.126 \\
\hline $\begin{array}{l}\text { SUBSIDY } \\
\text { US } \\
\text { non-US }\end{array}$ & $\begin{array}{l}0.090 \\
0.096\end{array}$ & 1.82 & 0.070 \\
\hline $\begin{array}{l}\text { VERTIN } \\
\quad \text { US } \\
\text { non-US }\end{array}$ & $\begin{array}{l}0.587 \\
0.564\end{array}$ & 1.73 & 0.085 \\
\hline
\end{tabular}

US: $n=261$

non-US: $\mathrm{n}=359$

in Table 3. The three linear models treat the ownership issue differently. Linear 1 includes only FOROWN to assess the impact of the extent of foreign ownership on export propensity. The linear 2 model examines the location of ownership issue by including dummy variables for U.S. TNCs, non-U.S. TNCS (WECJ) and state owned firms (STATE) while the default category is privately owned Brazilian firms. Models Linear 1 and Linear 2 are incorrect if the location of ownership influence is separate from the extent of foreign ownership influence. Linear 3 includes both the set of dummy variables and FOROWN to examine this issue. The possible danger of including both is multicollinearity. However, if the location and extent of foreign ownership are separate influences then models Linear 1 and Linear 2 are misspecified. All three linear models are included for comparison.

Several other studies have used the log-linear form when examining export behavior by firms although none has given a compelling theoretical reason for doing so (Glejser 1980, Katrak 1983, Lall and Mohammad 1983). A log-linear model is included in Table 3 for comparison. All four model specifications 
TABIE 3

Alternative Specifications of Regression Model*

\begin{tabular}{|c|c|c|c|c|}
\hline \\
\hline \multicolumn{5}{|c|}{ VARIABIE Linear 1} \\
\hline CONSTANT & $\begin{array}{c}0.00154 \\
(1.50)\end{array}$ & $\begin{array}{l}0.0018 \\
(1.33)\end{array}$ & $\begin{array}{l}0.0043 \\
(2.90)\end{array}$ & $\begin{array}{c}-1.42 \\
(1.62)\end{array}$ \\
\hline FOROWN & $\begin{array}{c}0.0207 \\
(3.35)\end{array}$ & & $\begin{array}{c}0.035 \\
(3.74)\end{array}$ & $\begin{array}{c}0.011 \\
(0.19)\end{array}$ \\
\hline CAPINT & $\begin{array}{c}7.81 \\
(9.31)\end{array}$ & $\begin{array}{c}6.79 \\
(8.54)\end{array}$ & $\begin{array}{c}6.55 \\
(8.27)\end{array}$ & $\begin{array}{c}0.299 \\
(3.39)\end{array}$ \\
\hline INAD & $\begin{array}{c}-30.20 \\
(1.62)\end{array}$ & $\begin{array}{l}19.47 \\
(1.06)\end{array}$ & $\begin{array}{c}-37.84 \\
(2.00)\end{array}$ & $\begin{array}{r}0.060 \\
(1.32)\end{array}$ \\
\hline CR4 & $\begin{array}{c}0.694 \\
(0.69)\end{array}$ & $\begin{array}{c}-0.535 \\
(0.52)\end{array}$ & $\begin{array}{c}-0.934 \\
(0.92)\end{array}$ & $\begin{array}{c}-0.004 \\
(0.13)\end{array}$ \\
\hline SUBSIDY & $\begin{array}{c}9.86 \\
(1.77)\end{array}$ & $\begin{array}{l}17.24 \\
(3.19)\end{array}$ & $\begin{array}{c}6.31 \\
(1.03)\end{array}$ & $\begin{array}{r}0.227 \\
(4.82)\end{array}$ \\
\hline US & & $\begin{array}{l}0.0024 \\
(1.68)\end{array}$ & $\begin{array}{l}0.0028 \\
(1.41)\end{array}$ & \\
\hline WECJ & & $\begin{array}{l}0.0001 \\
(0.07)\end{array}$ & $\begin{array}{l}0.0046 \\
(2.53)\end{array}$ & \\
\hline STATE & & $\begin{array}{c}-0.0032 \\
(0.89)\end{array}$ & $\begin{array}{l}-0.0053 \\
(1.44)\end{array}$ & \\
\hline 2 & & & & \\
\hline$\overline{\mathrm{R}}$ & 0.11 & 0.09 & 0.10 & 0.04 \\
\hline n & 1062 & 1062 & 1062 & 1062 \\
\hline$\underline{E}$ & 26.92 & 16.16 & 16.07 & 10.19 \\
\hline
\end{tabular}

* t-statistics in parantheses; critical $t$ at $95 \%=1.96$; at $90 \%=1.645$

exhibited heteroskedasticity which was corrected for using a weighted 2 least squares procedure. The results, presented in Table 3, are significant overall according to the F-statistic although the coefficients of determination are relatively low. Two factors contribute to the low R-squares: the data are essentially a cross-section sample; and the study uses the firm rather than the industry as the unit of analysis. Some other studies using firm level or industry data, have achieved similar coefficients of determination (Glejser 1980, Lall and Kumar 1981, Newfarmer and Marsh 1981 and Schneeweis 1985). Studies which report higher R-square only use industry level data (Katrak 1983, Lall and Mohammad).

The log-linear model does not appear to be superior to the three linear specifications. Only two coefficients are significant (CAPINT and SUBSIDY) while the model explains little of the variance in export propensity.

Among the linear models, each indicates that foreign ownership and capital intensity are important influences on export propensity. A simple test of means in Table 1 suggested that domestic firms and TNCs have the same export propensity. All three linear models, however, demonstrate that once other factors are controlled for, TNCs have higher propensities to export. In particular, 
U.S. TNCS in Linear 2 and non-U.S. TNCs in Linear 3 are superior to Brazilian firms as exporters. Since most U.S. TNCs are heavily foreign-owned (typically 90-100 percent) while there are greater variations in ownership arrangements (e.g. joint ventures) among non-U.S. TNCs, the inclusion of FOROWN in Linear 3 may reduce the explanatory power of the US dummy variable while enhancing that for WECJ.

Capital intensity is a significant, positive and large influence in every regression model. The result seems to run counter to the factor-intensities argument of international trade: with Brazil's relatively low wage structure, firms with high capital intensities should exhibit lower export propensities. This is not found here. As argued earlier, an alternative argument is that high-technology goods are better able to overcome marketing barriers to entry in the developed nations and increase export propensity. Yet another explanation is the product life cycle which suggests that mature, standardized production processes are sent to low-wage nations to achieve lower costs and goods are exported back to the developed nations.

The level of export subsidies given to the firm also has a strong positive influence on export propensities in all but one of the models (Linear 3) despite the measurement problems noted before. More accurate subsidy data, either the total grants to firms or a rate weighted by the composition of exports, would likely yield even better results. In two models, however, SUBSIDY is insignificant at the 95 percent level which suggests that some firms, perhaps TNCs in particular, are not sensitive to the government's export incentives as argued above.

Industry advertising is only significant in one model but nearly so in another. In each case its coefficient takes on the expected negative sign indicating that standardized manufactured products are easier to export from Brazil than highly differentiated ones.

The performance of the market structure variable CR4 is disappointing. It never achieves significance. Perhaps one explanation is that most Brazilian manufacturing industries are highly concentrated which allows for little variation in CR4. Another explanation is simply that market concentration alters firm export behavior in two ways: increased export propensity for those firms achieving significant economies of scale; or reduced export propensity if the competitive firms cannot achieve the size necessary for successful exportation and dominant firms choose to exploit the potentially large domestic market in Brazil.

As for the linear model specification, perhaps the appropriate one is Linear 3 which includes both the location (set of dummy variables) and the extent of foreign ownership. There are a greater number of significant coefficients than the other specifications and the multicollinearity problem mentioned earlier is apparently absent.

Conclusion

The overall results demonstrate that it is incorrect to only make direct sample comparisons across ownership groups and that studies which do so risk reaching improper conclusions. The Katrak hypothesis that the extent of foreign ownership exerts an important positive influence on the export behavior of firms is confirmed even when the location of firm ownership is considered as well. This suggests that parent firm management maintains some control over the operations of subsidiaries. Perhaps a measure of management structure (centralized vs. decentralized) could explain differences between firms with the same degree of foreign ownership but this possibility could not be explored given 
the data.

Location of foreign ownership is an independent influence on export propensity. Whether U.S. or non-U.S. TNCs are superior to Brazilian firms as exporters, however, depends on the model specification. Further research is needed to better determine if a consistent relationship between ownership location and export behavior exists or whether other factors (such as management structure or size of home market) render it insignificant.

There is mixed evidence on the effectiveness of subsidies. More accurate measurement or alternative specifications may be necessaryto separate the potentially different impact of export incentives on TNCs and Brazilian firms. The finding also suggests that an overall change in government policy may be necessary to increase the effectiveness of the export incentive program in Brazil. High tariffs in some industries may protect inefficient firms, particularly domestic ones, which face difficulty exporting their products. The policy mix rather than a specific export promotion policy may be the important factor on firm behavior.

Capital intensity exerts a postive, strong and consistent impact on export propensity. This positive sign indicates there is little evidence of comparative advantage at the firm level in manufacturing industries. Perhaps this suggests that global profit maximization for TNCs does not require strict adherence to comparative advantage.

Despite some theoretical arguments, market concentration never proves to be important. Similar results were obtained for a measure of product differentiation (industry advertising).

Finally, it is possible that these results are influenced by the presence of transfer pricing by TNCs. In a similar study of Brazilian manufacturing industries, there is some evidence, although weak, of TNCs overpricing imports (Natke 1985). The extent and direction of such behavior for exports is uncertain.

\section{NOTES}

1. This impact will hold for TNCs only as long as the production technology borrowed or purchased from the parent firm is up-to-date. If the product life cycle is correct, the tendency is for the parent firm to only transfer older technologies to their subsidiaries in developing nations. If this letter effect prevails, capital intensity may be an insignificant influence.

2. The specific weighting scheme is available from the author and was chosen according to a procedure suggested by Jan Kmenta, Elements of Econometrics, New York: Macmillan, 1971.

\section{$\underline{\text { References }}$}

1. Cohen, Benjamin, 1973, Comparative Behavior of Foreign and Domestic Export Firms in a Developing Country, Review of Economics and Statistics 55, 190-197.

2. Glejser, H., A. Jacquemin, and J. Petit, 1980, Exports in an Imperfect Competition Framework: an Analysis of 1446 Exporters, Quarterly Journal of Economics 94, 507-524.

3. Helleiner, Gerald K., 1981, Intrafirm Trade and the Developing Countries, (St.Martin's, New York). 
4. Helleiner, G.K., 1973, Manufactured Exports from Less Developed Countries and Multinational Firms, Economic Journal 83, 21-47.

5. Helleiner, G. K. and R. Lavergne, 1979, "Intrafirm Trade and Industrial Exports to the United States," Oxford Bulletin of Economics and Statis tics $41,297-311$.

6. Jenkins, Rhys, 1979, The Export Performance of Multinational Corporations in Mexican Industry, in: Sheila Smith and John Toye, eds., Trade and Poor Economies (Cass, Totowa, New Jersey) 89-107.

7. Katrak, Homi, 1983, Global Profit Maximization and the Export Performance of Foreign Subsidiaries in India, Oxford Bulletin of Economics and Statis tics 45, 205-222.

8. Lall, Sanjaya and Rajiv Kumar, 1981, Firm Level Export Performance in an Inward-Looking Economy: The Indian Engineering Industry, World Develop ment 9, 453-464.

9. Lall, Sanjaya and S. Mohammad, 1983, Foreign Ownership and Export Perfor mance in the Large Corporate Sector of India, Journal of Development Studies 20, 56-67.

10. Natke, Paul, 1985, A Comparison of Import Pricing by Foreign and Domestic Firms in Brazil, in Alan Rugman and Lorraine Eden, eds., Multinationals and Transfer Pricing (Croom-Helms, London).

11. Newfarmer, Richard S., and Lawrence C. March, 1981, Foreign Ownership, Market Structure and Industrial Performance:Brazil's Electrical Industry, Journal of Development Economics 8, 47-76.

12. Schneeweis, Thomas, 1985, A Note on International Trade and Market Structure, Journal of International Business Studies 16, 139-152.

13. Tavares, Maria Conceicao, 1978, Estrutura industrial e empresas lideres, (FINEP, Rio do Janeiro).

14. Tyler, William G., 1981, The Brazilian Industrial Economy, (D.C. Heath, Lexington, Mass.).

15. Vaitsos, Constautine, 1974, Intercountry Income Distribution and Transnational Enterprises (Clarendon: London).

16. White, Lawrence, 1974, Industrial Organization and International trade: Some Theoretical Considerations, American Economic Review 64, 1013-1020.

17. Wilmore, Larry, 1976, Direct Foreign Investment in Central American Manufacturing, World Development 4, 499-517. 